\title{
Fuelwood demand and supply in Rwanda and the role of agroforestry
}

\author{
J. D. Ndayambaje • G. M. J. Mohren
}

Received: 18 August 2010/ Accepted: 27 March 2011/Published online: 20 April 2011

(C) The Author(s) 2011. This article is published with open access at Springerlink.com

\begin{abstract}
Fuelwood in Rwanda is assumed to come from forests and woodlands, thus contributing to large-scale deforestation. Available studies on fuelwood demand and supply support this assumption and indicate a continuously rising demand of fuelwood, notably from forest plantations. These assertions are insufficiently substantiated as existing forest stock may not be depleted by rapid increase in demand for food and energy resources resulting from population growth, but rather from the need for agricultural land. Evidence suggests that the demands for fuelwood, in addition to other sources of energy, is supplied from agroforestry systems which has not been quantified so far. This review analyses sources and use of fuelwood in Rwanda, indicating the importance of on-farms trees and woodlots in fuelwood supply. It is concluded that the effect of fuelwood consumption on land use is difficult to disentangle as many other factors including land clearing for agriculture, livestock farming, human settlements, illegal cutting of valuable timber species,
\end{abstract}

J. D. Ndayambaje

Land and Forestry Research Centre, Forestry and

Agroforestry Research Unit, Rwanda Agricultural

Research Institute (ISAR), P.O. Box 138, Butare, Rwanda

J. D. Ndayambaje · G. M. J. Mohren ( $\square)$

Forest Ecology and Forest Management Group, Centre for Ecosystem Studies, Wageningen University, P.O. Box 47, 6700 AA Wageningen, The Netherlands

e-mail: frits.mohren@wur.nl the demand for charcoal in towns and past conflicts, contributed significantly to the high rate of deforestation in the country. If fuelwood demand is to be met on a sustainable basis, more fuelwood has to be produced on agricultural lands and in forest plantations through species site matching and proper management.

Keywords Agroforestry - Deforestation · Fuelwood demand · Fuelwood Supply · Forest plantations $\cdot$ Rwanda

\section{Introduction}

Rwanda is a small $\left(26,338 \mathrm{~km}^{2}\right)$, landlocked country in central Africa, situated at $1,500 \mathrm{~km}$ from the Indian ocean and at $2,000 \mathrm{~km}$ from the Atlantic ocean. Its population was estimated to be 10.7 million in January 2010 (CIA 2010), and mainly depends on natural resources for its livelihood. It is primarily dependent on agriculture, which is the way of life for about $90 \%$ of the population, most of them subsistence farmers. The total area of the arable land is estimated to be about $52 \%$ of the country's area (MINITERE 2004a). The remaining area is occupied by water, perennial crops and forests, nature reserves and settlements.

In Rwanda as in many developing countries, fuelwood is a major concern in any discussion on 
energy resources. This is shown by the fact that biomass (wood and crop residues) is the principal source of energy meeting $94 \%$ of national needs (MINITERE 2004b). In fact, $85 \%$ of the Rwandan population use firewood and $0.6 \%$ use charcoal to meet their energy demands (MINECOFIN 2003).

Other sources of energy such as hydropower, solar energy, biogas, peat, and methane gas are available but are not used widely. For instance, in 2004, only $6 \%$ of the Rwandan population was reported to have access to electricity (MININFRA 2004). The country imports all petroleum products, which makes them expensive and less accessible to a large proportion of the population.

In the Rwandan context, wood takes an important share in energy supply. It is being used in both urban and rural households for cooking and lighting. It also provides energy to a wide range of small scale industries and public institutions. Fuelwood supplies have always been considered as coming from forest plantations despite obvious availability of trees and shrubs in agricultural fields.

The need for food and wood as source of energy places a heavy burden on natural forests, and because of conservation interests, these forests have been designated as forest reserves with restricted community access and restricted use. Since 1960s, the need for fuelwood, together with the need to protect the high mountainous areas of Rwanda from erosion, called for the establishment of forest plantations. Also, agroforestry practices were promoted to intensify agricultural production and to provide wood and non-wood products at household level. As a result of conservation measures for natural forests, reforestation and on-farm tree planting activities, the annual deforestation rate declined from $2.9 \%$ between 1960 and 1970 (FAO 2005) to $1.8 \%$ between 1990 and 2010. This indicates that, although deforestation was ongoing, conservation measures and reforestation efforts counterbalanced this to some extent. Additional sources of wood, including fuelwood trees, were established in agricultural fields as part of agroforestry systems.

Despite all these efforts, an increasing gap between demand and supply of wood has been reported by the Forest Department. While agroforestry is practiced by many rural households, it is unclear how and under what circumstances trees and shrubs are integrated into crop production and to what extent they are useful in increasing agricultural production as well as the supply of wood and non wood products. Of particular concern is the lack of information on the contribution of the different agroforestry options in addressing the fuelwood scarcity.

Data on fuelwood demand and supply in Rwanda are based on surveys that have been carried out in different parts of the country, in urban and rural areas. Existing data mainly focus on the consumption side, without much emphasis on the supply side or resource base. Therefore, it is unclear to what extent fuelwood consumption causes deforestation, whether there is fuelwood shortage, and what measures have been adopted by rural households to address fuelwood or energy problems. What is common in most projection estimates is the expected and increasing gap between demand and supply of wood products from forests in relation to forest stocks and population projections.

The main objective of this paper is to review the situation of fuelwood in Rwanda and to assess the potential of forests and agroforestry systems combined, to provide fuelwood for the growing population. The review discusses fuelwood consumption and analyzes the projected fuelwood demand and supply, linking this to the high deforestation rate reported for the country.

\section{Fuelwood sources}

Natural forests and woodlands

The country's largest natural forests are Nyungwe in the Southern Province, the Volcanoes National Park in the Northern Province, and the forests within the Akagera National Park in the Western Province (Fig. 1). There are also other small natural forests, gallery and savannah woodlands designated as natural reserves, such as the Mukura forest, the forests of Cyamudongo and Busaga, and the savannah of the east (MINITERE 2005). The total area under natural forests in 2002 was estimated to be 233,900 ha (Table 1).

It should be noted that before the colonial era, Rwanda may have had much less trees than at present in certain locations. Journals from the early days of the colonial time show landscapes with much less 


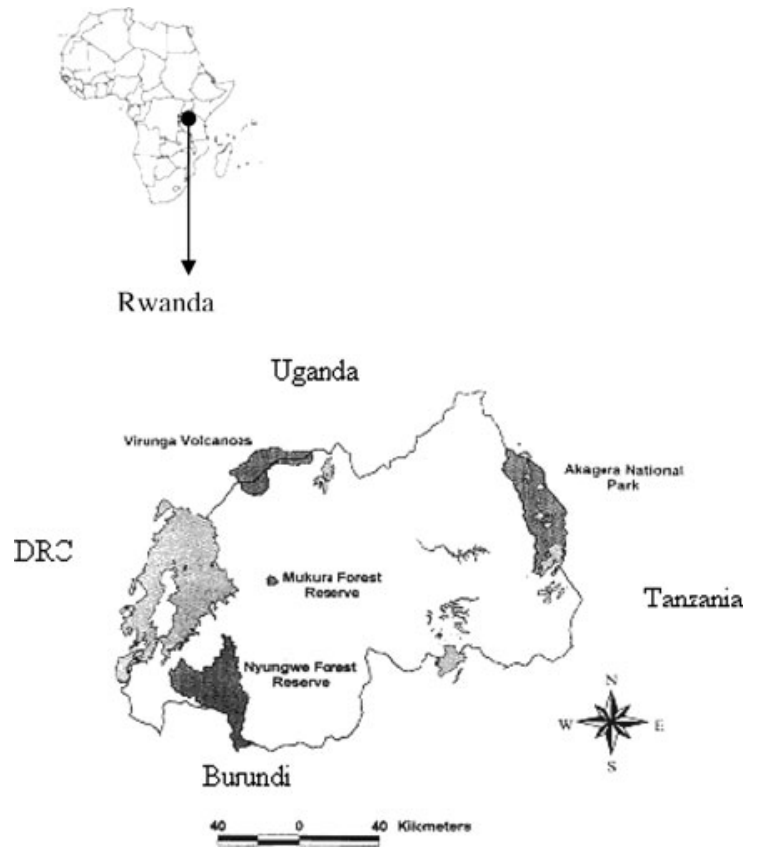

Fig. 1 Location of major natural forests in Rwanda

Table 1 Area of natural and protected forests in 2002 (MINITERE 2004c)

\begin{tabular}{lr}
\hline Forests & Area (ha) \\
\hline 1. Nyungwe + Cyamudongo & 101,500 \\
2. Gishwati & 600 \\
3. Mukura & 800 \\
4. Birunga (Volcanoes) & 16,000 \\
5. Akagera & 90,000 \\
6. Gallery & 25,000 \\
Total & 233,900 \\
\hline
\end{tabular}

trees than today. A good illustration is the comparison of the present view from the Kandt Museum of Natural History at Kigali, and the picture taken almost 100 years ago from the same spot, showing Mount Kigali and its neighbourhood virtually without trees. Toward the end of the 1920s, planted forests were estimated at 380 ha (Biroli 1982).

The use of natural forests for wood and non wood products has undergone various changes in recent history. During the pre-colonial period before 1924, these forests were managed under a wide range of state and communal tenure arrangements. These arrangements led to depletion of the resources through agriculture and grazing. Forest clearing for crop production and pastures was done without control as forests were considered common property.

During the colonial period between 1924 and 1934, the Belgian Colonial Authority restricted the use of natural forests by adopting forest legislation that prohibited forest clearing for agriculture, but recognized community rights to cut and collect firewood and commercial exploitation of valuable timber. Although these forests were declared official reserves by the Belgian Colonial Authority, enforcement of the regulations was frequently absent or irregular. As a result, the population continued to encroach on natural forests in search for land, wood and non-wood products.

During the post independence period after 1962, the use of forests was regulated by a new forest law. As an example, access to resources in Nyungwe forest in the southwest of the country was limited to a multiple-use zone where controlled harvesting of products was allowed, and in the buffer zone plantations around it (Weber 1989). Nevertheless, local people have continued to collect resources from forests, resulting in conflicts between the management of the forest and the local communities.

Under the current forest law, natural forests in Rwanda have special conservation status. Removal of wood products, including fuelwood gathering, is prohibited. Despite this, many studies have indicated that these forests remain an important source of fuelwood and other products for people living around them (Hoster and Milukas 1992; Monela et al. 1999; Warner 2000; Campbell et al. 2002; Cavendish 2002; Masozera and Alavalapati 2004; Bird and Dickson 2005).

Local consumption by forest fringe communities usually has been in the form of collection of deadwood and branches. Significant amount of fuelwood for local consumption as well as for charcoal production for sale in town were obtained along with massive and extensive clearance of forests. The management of buffer zones, for example around Nyungwe Forest, is an attempt at creating a source of wood and non-wood products from forest plantations while protecting the reserve itself from illegal use.

Forest plantations

The earliest reforestation efforts, dating from 1920 to 1948, had the dual function of protecting mountaintop 
areas from erosion, and supplying fuelwood (Amsallem et al. 2002). The objective was to afforest one ha of woodland for 100 persons (Biroli 1980). After Independence in 1967, some 20,000 ha of communal land were afforested. Of this plantation area, the first forestry project in the country, Kibuye Pilot Forestry Project, established 5,500 ha of planted forests. Intensive reforestation efforts were carried out between 1975 and 1989, with planted areas rising from 27,160 ha in 1975 to 247,500 ha in 1989. Plantation area expanded up to 1994 , when all economic and development activities stopped following war and the Tutsi genocide.

In addition to the establishment of plantations, fast growing tree species were disseminated in rural areas in order to meet the increasing demand for fuelwood and construction materials by the rapidly growing population. Eucalyptus species received much attention due to their fast growth, coppicing ability, caloric value and adaptability to a wide range of soils and climate. In 1990, Eucalyptus species occupied $65 \%$ of the total plantation area (Table 2). Some 10 Eucalyptus species are found in rural landscape, the most common being Eucalyptus camaldulensis Dehnh, E. globulus Labill., E. grandis W. Hill ex Maiden, E. saligna $\mathrm{Sm}$. and E. tereticornis $\mathrm{Sm}$.

Next to Eucalyptus spp., Pinus spp. have also been widely planted. Other tree species in planted forests include Acacia melanoxylon R. Br. Ex Aiton,
Callitris robusta F. Muell, C. calcarata (A. Cunn.) R. Br., Grevillea robusta A. Cunn., Casuarina equisitifolia L. and C. cunninghamiana Miq. A few local tree species such as Polyscias fulva (Hiern) Harms, Podocarpus falcatus (Thunb.) R. Br. ex Mirb., P. latifolius (Thunb.) R.Br. ex Mirb., Maesopsis eminii Engl. and Albizzia spp. were planted, particularly in buffer zones around indigenous forest reserves (Habiyambere 1999).

Figure 2 gives the changes in area of forest plantations. Between 1970 and 1990, the plantation area quickly expanded from 27,160 ha to 247,500 ha. This was a result of tree planting campaigns and actions by large development projects providing financial and technical support to forest sector development. Between 1990 and 1994, all this stopped because of war and genocide. During this period, the forest area declined by 15,000 ha, mainly due to agricultural expansion, establishment of new settlements and illegal tree harvesting. An additional 25,000 ha of forest plantations were damaged (Habiyambere 1999). In 1995, reforestation activities started again, including rehabilitation of damaged plantations.

A large reforestation effort increased forest cover by an average of $8 \%$ per year between 2000 and 2005 (FAO 2005). Recent forest mapping of forest plantation area $\geq 0.5$ ha by the Centre for Geographic Information Systems and Remote Sensing of the

Table 2 Distribution of forest plantations by tree species and ownership in 1990 (Mihigo 1999)

\begin{tabular}{|c|c|c|c|c|c|c|c|c|}
\hline & \multicolumn{8}{|l|}{ Ownership } \\
\hline & \multicolumn{2}{|l|}{ State $^{a}$} & \multicolumn{2}{|c|}{ Institutional $^{\mathrm{b}}$} & \multicolumn{2}{|l|}{ Private $^{\mathrm{c}}$} & \multicolumn{2}{|l|}{ Total } \\
\hline & Area (ha) & $\%$ & Area (ha) & $\%$ & Area (ha) & $\%$ & Area (ha) & $\%$ \\
\hline Eucalyptus spp. & 30,600 & 50 & 69,370 & 70 & 61,040 & 70 & 161,010 & 65 \\
\hline Pinus patula & 18,360 & 30 & 9,910 & 10 & 4,360 & 5 & 32,30 & 13 \\
\hline Cupressus lusitanica & 4,900 & 8 & 7,930 & 8 & 8,720 & 10 & 21,550 & 9 \\
\hline Acacia menaloxylon & 4,280 & 7 & 6,940 & 7 & - & - & 11,220 & 5 \\
\hline Callitris spp. & 1,830 & 3 & 2,970 & 3 & - & - & 4,800 & 2 \\
\hline Grevillea robusta & - & - & - & - & 4,360 & 5 & 4,360 & 2 \\
\hline Casuarina spp. & 1,230 & 2 & 1,980 & 2 & - & - & 3,210 & 1 \\
\hline Others & - & - & - & - & 8,720 & 10 & 8,720 & 3 \\
\hline Total & 61,200 & 100 & 99,100 & 100 & 87,200 & 100 & 247,500 & 100 \\
\hline
\end{tabular}

\footnotetext{
${ }^{a}$ State forests include all forests plantations established by government projects, donor-funded projects and all plantations established on government land during the tree planting days and communal work

b Institutional forests are those owned by such institutions as churches, educational institutions, and local districts

c Private plantations include individual woodlots and plantations by individuals, private enterprises such as tea factories
} 


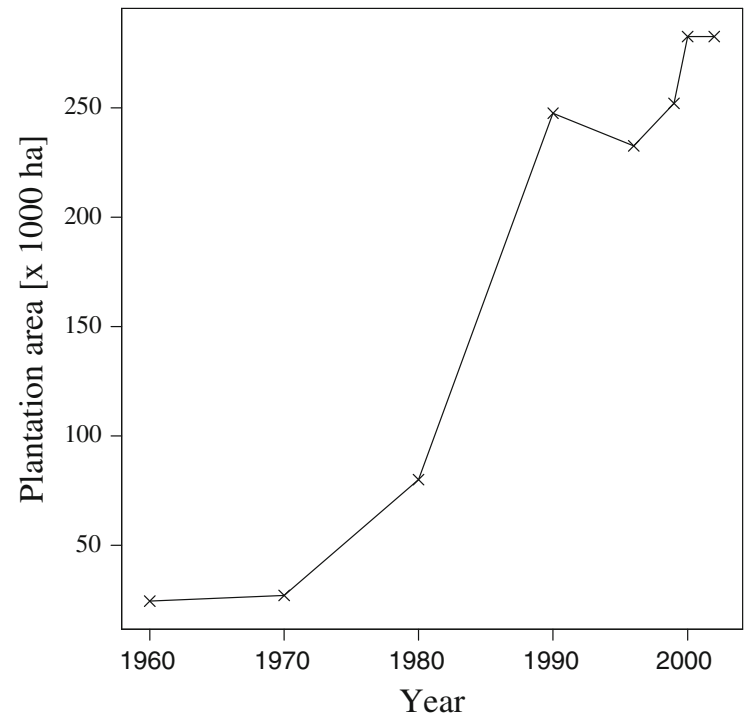

Fig. 2 Evolution of forest plantation area between 1960 and 2002 (MINITERE 2005)

National University of Rwanda reported a forest plantation area of about 114,000 ha in 2007 and an average reforestation rate of 2,600 ha between 1988 and 2007 (MINIRENA/CGIS-NUR 2008). Since the mapping included only forest plantation areas $\geq 0.5 \mathrm{ha}$, the total area as reported is an underestimate because it does not account for trees and woodlots on farms despite the fact that these tree resources constitute a major source of fuelwood and income to rural people.

Eucalyptus spp. are most commonly used for plantation forests and on-farm woodlots. Next to multiple uses and advantages, eucalyptus woodlots have come under increasing criticism from politicians and environmentalists because of its alleged negative environmental impact on soil nutrients and hydrology, to the extent that it is suggested that they should be eliminated from marshlands and bottomlands, and prohibited in reforestation in the country (Gahigana 2006).

However, some authors (e.g. Nshubemuki 1988; Munyarugerero 1988; Davidson 1995; White 1995; El-Amin et al. 2001) indicated that the adverse effect of eucalyptus plantations on soils and hydrology is not universal but depends on species, site characteristics and management practices. The problem is related to water use and nutrient uptake by eucalyptus. Where water is scarce, water use by eucalypt plantations may continue longer than in the case of other species, but this might be reduced by planting fewer trees per unit area or by thinning. Depending on management objectives, careful selection of species, planting sites and management practices are required in order to maintain productivity and minimise the negative effects of eucalyptus plantations and woodlots on soil nutrients and water.

In Rwanda, eucalyptus plantations cover about 63,561 ha or $26 \%$ of the total forest area in 2007 (MINIRENA/CGIS-NUR 2008). These figures do not include coppices and young eucalyptus stands because the mapping has taken into account only stands with height equal or greater than $7 \mathrm{~m}$ and tree cover of at least $20 \%$. As result, total area and standing volume is likely to be somewhat underestimated.

The productivity of existing plantations is generally reported to be rather low, and varies with planting location and tree species. Table 3 shows the mean annual increments of main plantation tree species recorded in Rwanda. The productivity rate is as low as $6-10 \mathrm{~m}^{3} \mathrm{ha}^{-1}$ year $^{-1}$ in some cases. The low yields of most forest plantations are mainly due to low site quality, inadequate selection of species and provenances, and inappropriate management techniques during planting, thinning, and harvesting.

Using $10 \mathrm{~m}^{3} \mathrm{ha}^{-1}$ year ${ }^{-1}$ as the average productivity rate, the 240,708 ha of forest plantations may yield 2.4 million $\mathrm{m}^{3}$ of wood per year. Based on FAO (2005) estimates that $72 \%$ of total wood removal from forests in Rwanda consists of fuelwood, the volume of wood (to be converted into biomass) that could be harvested on sustainable basis to supply fuelwood would be about 1.7 million $\mathrm{m}^{3}$ for a Rwandan population of 10.7 million (January 2010). Hence the theoretical sustainable supply of wood for energy would be $0.16 \mathrm{~m}^{3}$ person $^{-1}$ year $^{-1}$, which is less than a quarter of the consumption of

Table 3 Productivity of main plantation tree species in Rwanda (MINIRENA/ISAR 2008)

\begin{tabular}{lc}
\hline Tree species & $\begin{array}{l}\text { Productivity } \\
\left(\mathrm{m}^{3} \mathrm{ha}^{-1} \mathrm{year}^{-1}\right)\end{array}$ \\
\hline Acacia melanoxylon & 15.0 \\
Callitris robusta & 5.8 \\
Cupressus lusitanica & 6.8 \\
Eucalyptus species & 6.9 \\
Grevillea robusta & 10.0 \\
Pinus spp. & 13.1 \\
\hline
\end{tabular}


$0.91 \mathrm{~m}^{3}$ person $^{-1}$ year $^{-1}$ found by the national wood consumption survey in 1982 .

The annual production of existing forest plantations is therefore considered to be insufficient to meet the current fuelwood demand for the population, and the discrepancy will increase with increasing population. Even with additional plantations on estimated area of approximately 81,000 ha (MINIRENA/CGISNUR 2008), higher biomass production in forest plantations cannot be achieved without silvicultural treatments and selection of species that perform well on land usually of marginal quality.

\section{Agroforestry systems}

Under agroforestry, trees and shrubs are grown in agricultural fields in association with crops, either as single trees, linear formations or woodlots. These trees produce goods such as fuelwood, stakes for climbing beans, fodder, building poles, timber, and fruit and medicines, and provide service functions such as soil conservation and soil fertility replenishment. Den Biggelaar and Gold (1996) reported that both indigenous and exotic tree species were appreciated by farmers and used in agroforestry systems. This indicated that these tree species were considered by farmers as being less competitive to crops and have minimal negative effects on soils (i.e. less allelopathic effects and efficient use of water and nutrients). So far, 152 tree species have been recorded, of which 60 species are used as fuelwood (Den Biggelaar 1996).

Despite limited farm sizes in Rwanda, farmers incorporate trees and shrubs within small farms by choosing appropriate locations for planting multipurpose tree species. Survey data reported by Samyn (1993) showed that the average wood production in the farming systems was approximately $1.5 \mathrm{~m}^{3} \mathrm{ha}^{-1}$ year $^{-1}$. As a result, smallholder farmers in general will not be able to produce all the fuelwood and other wood products they need for domestic use on their own farmland.

Theoretically, a national average of 0.6 ha of family farm may satisfy the energy needs for cooking for a family of six members. On such small farms, it is possible to incorporate trees by using agroforestry practices such as boundary planting, alley cropping and short term improved fallows with fast growing and less competitive tree species. The planting of selected tree species in spatial and temporal combination with agricultural crops can be practised to fulfil service and productive functions of which fuelwood supply is one.

The use of fuelwood from agricultural fields frees rural households from gathering fuelwood from forests and wooded lands. The production and consumption of fuelwood from agroforestry systems thus can release the burden of long time collection of wood for energy by children and women in rural areas, albeit at the cost of increased competition with food crops.

Agroforestry shrubs that are established on farms combine fuelwood production with soil erosion control, stakes for climbing beans, green manure and fodder for livestock (Roose et al. 1993).The desirable characteristics of tree and shrub species that fit the requirements for fuelwood species include nitrogen fixing ability, rapid growth, coppicing ability and ability to grow in degraded and deficient soils ((Nair 1987; Mead 2005). In order to increase food production as the main objective, agroforestry species that ensure increased efficiency of fertilizer use (Breman and Kessler 1995) should be considered as an important criteria for choosing tree species that will enhance food production and fuelwood supply. These tree species, also referred to fertilizer trees, go beyond the production of food. They also conserve the natural resource base and protect the environment. Such fertilizer trees including Calliandra calothyrsus, Gliricidia sepium, Leucaena diversifolia, Senna spp., Sesbania sesban and Tephrosia vogelii have been identified as outstanding fuelwood species. Regular harvesting of these trees for fuelwood may result in a substantial removal of nutrients, depending on management. Significant nutrient removals can result from harvesting branches for firewood because of the higher nutrient content in branch wood and bark. These materials should be left on the field and incorporated into the soils in combination with mineral fertilizers in order to increase crop yields. In Tanzania, fertilizer trees were able to provide up to $10 \mathrm{t}$ of wood biomass per hectare, thereby sequestering 2.5-3.6 $\mathrm{t}$ of carbon per hectare per year (Nyadzi 2004)

Many surveys in Rwanda (e.g. AFRENA 1988; Den Biggelaar 1996; Mukuralinda et al. 1999) reported the utilization of less suitable fuelwood species for energy supply such as Vernonia 
amygdalina Del., Euphorbia tirucalli and Ficus thonningii. The use of these tree species indicates farmers' strategies to address fuelwood problems. Table 4 shows a short list of promising fuelwood species in the highlands, midlands and lowlands of Rwanda. Data on coppicing ability, yield and wood specific gravity are given for some species to give an indication of the potential value of the species as fuelwood. Current and potential agroforestry practices that could provide fuelwood while ensuring agricultural intensification are presented and discussed below.

\section{Scattered trees on-farms}

The use of scattered trees and shrubs is a traditional practice in the various land use systems in the country. The intensification of agricultural production results from the ability of the system to improve soil fertility, and to provide shade and mulch to associated crops. In this system, trees are managed to produce timber, firewood, fodder, poles, fruit, and bean stakes. In banana and coffee plantations, overstorey trees with light shade are preferred by farmers in order to reduce competition for growing space and light with crops (Djimde 1988).

Indigenous tree species including Markhamia spp., Acacia spp., Ficus spp., Polyscias fulva and Erythrina abyssinica are commonly found in land use systems as scattered or isolated trees. Among exotic tree species, Grevillea robusta A. Cunn. ex $\mathrm{R}$. Br. is widespread and is often intercropped with banana and coffee in order to provide firewood, stakes for climbing beans and mulch. Experiences within the Projet Agropastoral de Nyabisindu on the central plateau of Rwanda indicated that with 350 trees of Grevillea per hectare, the annual yield after 9 years was $14.6 \mathrm{~m}^{3} \mathrm{ha}^{-1}$ year $^{-1}$ of wood and $3.07 \mathrm{t} \mathrm{ha}^{-1}$ year $^{-1}$ of fresh leaves (Kerkhof 1990). Branches lopped from grevillea are commonly used as fuelwood or as stakes for climbing beans.
Table 4 Firewood species for the high, medium and low elevation zones of Rwanda

\begin{tabular}{|c|c|c|c|}
\hline Species & Coppicing ability & Yield $\left(\mathrm{m}^{3} \mathrm{ha}^{-1}\right.$ year $\left.^{-1}\right)$ & Specific gravity \\
\hline \multicolumn{4}{|l|}{ (a) High elevation zones } \\
\hline Acacia mearnsii & Yes & $10-25$ & $0.50-0.70$ \\
\hline Alnus nepalensis & Yes & $10-15$ & $0.32-0.37$ \\
\hline Alnus acuminata & Yes & $10-15$ & $0.50-0.60$ \\
\hline Mimosa scabrella & Yes & & \\
\hline Chamaecytisus palmensis & Yes & $15-20$ & \\
\hline Melia azedarach & Yes & & 0.66 \\
\hline $\begin{array}{l}\text { Sesbania sesban } \\
\text { (b) Medium elevation zones }\end{array}$ & Yes & 2 t stems ha ${ }^{-1}$ year $^{-1}$ & \\
\hline Grevillea robusta & Poor but pollards & & 0.57 \\
\hline Calliandra calothyrsus & Yes & $5-15$ & \\
\hline Leucaena diversifolia & Yes & $15-40$ & $0.45-0.55$ \\
\hline Eucalyptus globulus & Yes & $10-60$ & $0.80-1.00$ \\
\hline $\begin{array}{l}\text { Jacaranda mimosifolia } \\
\text { (c) Low elevation zones }\end{array}$ & Yes & 20 & $0.45-0.72$ \\
\hline Gliricidia sepium & Yes & & \\
\hline Senna spp. & Yes & 15 & $0.6-0.8$ \\
\hline Azadirachta indica & Yes & $13-17$ & 0.68 \\
\hline Casuarina cunninghamiana & Not readily & & \\
\hline Casuarina equisitifolia & Not readily & 15 & \\
\hline Eucalyptus camaldulensis & Yes & $17-25$ & 0.60 \\
\hline Eucalyptus citriodora & Yes & 15 & $0.75-1.00$ \\
\hline Eucalyptus tereticornis & Yes & $20-25$ & $\geq 0.75$ \\
\hline
\end{tabular}


In the highlands of Rwanda where annual rainfall is between 1,300 and $1,800 \mathrm{~mm}$, scattered eucalyptus trees or trees planted at wide spacing are found growing together with food crops in agricultural fields (Nduwamungu et al. 2007). However, in all land use systems, fruit tree species including Persea americana, Mangifera indica, Carica papaya and Citrus spp. are also found, mostly as isolated trees near the home compound.

\section{Woodlots}

The most common tree species used in on-farm woodlots are Eucalyptus spp. (mostly E. camaldulensis and E. tereticornis) followed by Grevillea robusta (Balasubramanian and Sekayange 1992). Small eucalyptus woodlots are found in all farming systems of Rwanda. Farmers who own woodlots target fuelwood production, followed by building poles (Den Biggelaar 1996). Because of land scarcity, only $8.5 \%$ of agricultural households own on-farm woodlots (NISR 2010). A recent study regarding woodlots from 0.06 to 5.20 ha concluded that very small woodlots are not profitable and that the maximum benefit can be obtained for a woodlot of 0.5 ha (GTZ 2008). Since the average farm size in Rwanda is about 0.75 ha, only those few farmers who own larger land areas may benefit from woodlots.

Exotic potential fuelwood shrubs for growing in on-farm woodlots include Calliandra callothyrsus, Senna spectabilis, S. siamea (Lam.) H.S. Irwin \& Barneby, Gliricidia sepium (Jacq.) Kunt ex Walp, Mimosa scabrella Benth., Sesbania sesban (L.) Merrill. and Leucaena spp. These species are fast growing and respond positively to frequent cutting. However, their yields are location-specific and vary under different agroecological zones and silvicultural treatments. Results from fuelwood production trials in the Kakamega district of Kenya, similar to many environments in Rwanda, showed total aboveground biomass yields of 34 and $62 \mathrm{tha}^{-1}$ year $^{-1}$ fresh weight at 10,000 and 40,000 stems ha ${ }^{-1}$ in Calliandra calothyrsus, 46 and $81 \mathrm{t} \mathrm{ha}^{-1}$ year $^{-1}$ in Sesbania sesban, 34 and $35 \mathrm{t} \mathrm{ha}^{-1}$ year $^{-1}$ in Mimosa scabrella at similar stocking densities (Kerkhof 1990). These figures indicate that fuelwood production potential in woodlots using fast growing and coppicing tree species can be very high.
Tree legumes planted along contour lines and erosion control ditches

Depending on biophysical conditions of the site, farmers may use legume tree species such as Calliandra calothyrsus, L. diversifolia, Senna spectabilis and Alnus spp. to reduce runoff and control soil erosion. Periodic cutting of these shrubs provide fodder for animals, fuelwood for cooking, stakes for climbing beans, and green manure for soil amelioration. Overstorey tree species such as Grevillea robusta and Cedrela serrata may also be integrated into hedgerows of shrubs (Balasubramanian and Sekayange 1986). At maturity, overstorey trees provide timber and fuelwood.

\section{Alley cropping with tree legumes}

Alley cropping is one of the agroforestry systems in which food crops are grown in alleys formed by the hedgerows of shrubs that are periodically pruned during cropping to prevent shading, to reduce intercrop competition for moisture and nutrients, and to provide green manure for the associated food crops. On sloping farmlands, alley cropping may lead to terrace formation, minimising water runoff and soil erosion (Kabaluapa et al. 2008). Additionally, the woody portion of pruned stems provide fuelwood and stakes for climbing beans. Leaves may also be used as protein-rich fodder for livestock.

The suitability of alley cropping system for the highland and the semi-arid regions of Rwanda was investigated by various researchers (e.g. Yamoah et al. 1989; Yamoah and Burleigh 1990; Balasubramanian and Sekayange 1992) by use of tree legumes such as L. diversifolia, Calliandra callothyrsus, Senna spectabilis and Sesbana sesban. As found by Balasubramanian and Sekayange (1992), the mulch from green lopping improved soil fertility, with little or no reduction in crop yields. Additionally, Experiments with Calliandra calothyrsus, Senna spectabilis and Leucaena leucocephala (Lam.) de Wit in the semi arid zone of Bugesera, Rwanda, led to the production of fuelwood of 3.7-5.0 $\mathrm{tha}^{-1}$ year $^{-1}$ (Balasubramanian and Sekayange 1992). Gliricidia sepium (Jacq.) Walp. is also a promising fuelwood species. Under favourable environmental conditions (annual rainfall of $900-1,500 \mathrm{~mm}$, elevations of 0-1,200 m, deep and well drained fertile soils), this 
species is capable of producing 3.6-7.1 $\mathrm{t} \mathrm{ha}^{-1}$ year $^{-1}$ dry weight of fuelwood (FAO 1993). Evidently, such productivity will have consequences for crop yield, as competition will increase and crop yield will decrease with increasing resource capture by the trees. In the case of alley cropping, competition between trees and crops cannot be avoided, and the farmer will have to consider the trade-off between production of agricultural crops and the growth of trees.

The coppicing ability of many multipurpose shrubs makes them produce substantial amounts of stem biomass that can be used as fuelwood. For leucaena and sesbania, the number of coppice shoots per stump increases with stump height (Misra et al. 1995). Dry matter production in hedgerows of $L$. leucocephala and Calliandra calothyrsus are higher for calliandra (124-196 kg/100 m hedge) than leucaena (66-102 kg/100 m hedge/year) when cut at different cutting heights (Newmann and Pietrowicz 1986). Converted to a per hectare basis, these yields in hedgerows correspond to theoretical annual dry matter production of approximately 4-6 $\mathrm{t} \mathrm{ha}^{-1}$ for L. leucocephala and 10-16 t ha ${ }^{-1}$ for Calliandra callothyrsus.

Generally, the highest productions are due to high coppicing ability and fast growth rates that allow successive harvests, sometimes three times, within a year. This is the case for some agroforestry species (e.g. Mimosa scabrella, Jacaranda mimosifolia D. Don, and Alnus acuminata Kunt) that have been identified for their adaptability and growth in various parts of the country by agroforestry research from 1980s.

Compared to tree blocks, alley cropping produce progressively more mulch and hence yield significantly higher nutrient masses. In Benin, the cut dry matter produced from five cuttings of Gliricidiasepium and Flemingiamacrophilla per cropping season ranged from 855 to $1,651 \mathrm{~kg} \mathrm{ha}^{-1} \mathrm{yr}^{-1}$ for alley hedges and from 777 to $869 \mathrm{~kg} \mathrm{ha}^{-1} \mathrm{yr}^{-1}$ for tree block (Böhringer and Leihner 1997). Topographic conditions and land scarcity in Rwanda make alley cropping a promising agroforestry system that can contribute to erosion control, soil fertility replenishment and provision of fuelwood for cooking in rural households.

\section{Boundary planting}

Boundary planting involves the planting of trees along the perimeters of farmers' properties for land delimitation, timber, fuelwood, soil conservation and wind protection. This system may also provide secondary benefits such as fodder, mulch and stakes for climbing beans. Less shading tree species that not compete with crops are used. By managing this system, farmers are able to continue cropping trees right up to the edge of the homestead. Most farmers in Rwanda are found to use Grevillea robusta, Cupressus lusitanica, Euphorbia tirucalli, Erythrina abyssinica, and Dracaena afromontana to demarcate farm and plot boundaries. The first two tree species are large size trees commonly used in plot demarcation, boundary marking, stabilization of roads and as windbreaks. In addition to fuelwood, they are also used for other products including construction poles and timber.

\section{Live fences}

Live fences with indigenous shrub species such Euphorbia spp. and some exotic tree species such Calliandra calothyrsus, L. diversifolia, and Senna spp. are also established into hedges around farms and homestead in order to provide fodder for farm animals, mulch and to protect planted crops from livestock damages. Besides their main function live fences can provide fuelwood, act as wind breaks or control erosion, depending on the species used.

\section{Improved fallows}

Many researchers in agroforestry (e.g. Buresh and Cooper 1999; Nakakaawa et al. 2004; Kwesiga and Coe 1994) have found that fallow technologies with multipurpose shrubs increase yields of subsequent crops and that large amount of harvested woody biomass can be used as fuelwood. Owing to the severe land shortage, fallowing is impractical for the majority of agricultural households in Rwanda. However, agroforestry research and development in Rwanda and in other countries in Africa found that improved fallows, that involve the rotation of planted $\mathrm{N}$-fixing trees with crops, can produce substantial amount of fuelwood next to improving soil fertility and soil structure (Kwesiga and Coe 1994; Sanchez et al. 1996; Mafongoya and Dzowela 1999; Banzi et al. 2004; Pye-Smith 2008).

Studies on fuelwood consumption in Zambia confirmed that $11 \%$ of firewood consumed by rural households comes from improved fallow fields 
(Govere 2002). In Eastern Zambia, Sesbania sesban improved fallows produced 15 and $21 \mathrm{t} \mathrm{ha}^{-1}$ of fuelwood after 2 and 3-year fallows, respectively (Kwesiga et al. 1999) while in western Kenya, 15 and $21 \mathrm{Mg} \mathrm{ha}^{-1}$ of fuelwood were harvested from sesbania fallows after two and three years, respectively (Kwesiga and Coe 1994). In the same region, on small plots of $0.01-0.08$ ha planted to improved fallows, Jama et al. (2008) concluded that the actual fuelwood harvested from the plot would last a typical household between 11.8 and 124 days depending on legume tree species and fallow duration. Further, they argued that this would increase to 268.5 and 1173.7 days if farmers were to increase the area planted to 0.25 ha.

The foregoing supports the view that improved fallows may provide ample quantities of fuelwood. More importantly, the use of these fertilizer trees increase the yields of subsequent crops. A recent meta-analysis from 94 studies published in SubSaharan Africa concluded that fertilizer tree systems could double and even triple the yields of maize (Sileshi et al. 2008). In Kenya, 53 and $42 \%$ increase in maize yields were recorded for L. leucocephala and Gliricidia sepium, respectively (Akinnifesi et al. 2006). In Zambia, sesbania fallows were reported to have increased maize yields by $500 \%$ (Chirwa et al. 2003) while in Tanzania, the improved fallows with tephrosia and sesbania increased maize yields to 40 and $68 \%$, in that order (Gama et al. 2004).

The benefits of fallows depend upon biomass accumulation; longer fallow periods generally result in greater increases in crop yield and residual effect (Kwesiga et al. 1999). However, Land scarcity and high population density in Rwanda make extended fallow periods impractical to smallholder farmers. The latter practice continuous cultivation to produce food crops for their families. Improved fallow can be practiced in the Eastern Province where the average area by agricultural household is 1.1 ha (larger than the national average of $0.76 \mathrm{ha}$ ).

Alternatively, relay fallow cropping with $\mathrm{N}_{2}$ fixing trees is a form of improved fallow technology in farming systems where landholdings are small. The system allows concomitant cultivation of trees and crops (ex. Maize), with fixation of $\mathrm{N}$ (sesbania, tephrosia, gliricidia). Relay fallow cropping with sesbania or tephrosia was found efficient in southern Malawi where the average landholding was 0.4 ha and the population density $300-500$ persons $\mathrm{km}^{-2}$ (Akinnifesi et al. 2009).

\section{Fuelwood consumption}

Various reports have presented data describing the fuelwood consumption and supply in the country. Unfortunately, the majority of existing figures are historical or estimations used to justify the assumed impact of fuelwood consumption on forest stock and the balance between the demand and supply of wood products including fuelwood. Considerable amount of data on wood consumption have been generated in the past and speculations about fuelwood demand and supply balances have been based on these data. Different government institutions generated data on wood consumption at different periods of time (e.g. MINAGRI 1983; MINITRAPE 1992; MINECOFIN 2003). A study conducted in 1993 by Hategeka (1997) focussed on fuelwood and residue use in the long rainy season and long dry season in four different parts of the rural areas of the country and in 48 institutions in Capital Kigali, and concluded that fuelwood contributes more than $80 \%$ of all energy used in the country.

Per capita fuelwood consumption has been given into different units, in $\mathrm{kg}$ or in $\mathrm{m}^{3}$ of wood or vegetable materials, or in the percentage of the population using a given source of energy. In most cases, data on fuelwood consumption was derived by multiplying estimated per capita consumption with population figures. A more recent survey conducted in 1993 estimated the average daily consumption of fuelwood in households at $1.33 \mathrm{~kg}$ of air dried wood per person per day (Hategeka 1997). This amounts to $486 \mathrm{~kg}$ of dried wood per person per year, equivalent to $0.67 \mathrm{~m}^{3}$ per capita per year. ${ }^{1}$

Between 1981 and 1982, an average per capita firewood consumption of $0.83 \mathrm{~m}^{3}$ year $^{-1}$ was reported by MINAGRI (1983). Using the long term monitoring methods of measuring biomass consumption, Karenzi (1994) estimated the daily consumption of fuelwood in rural Rwanda to be $0.91 \mathrm{~kg}$ per capita, i.e. $0.5 \mathrm{~m}^{3}$ year $^{-1}$.

\footnotetext{
1 Author's estimate based on a fuelwood density of $725 \mathrm{~kg} \mathrm{~m}^{-3}$ (FAO 2004).
} 
Differences in fuelwood consumption data arise from different sampling designs and different methodologies that have been used at different periods and localities. Sample sizes varied from less than 100 households to approximately 1,000 households in selected administrative units distributed over the country. Obviously, the question arises on how to select a representative household in fuelwood consumption study in a country with different agroecological zones and socio-economic characteristics of resident populations.

Although data on fuelwood consumption are available, no information is provided on the total demand in order to establish the balance between demand and consumption. Since many surveys on fuelwood consumption indicated the use of crop residues as supplementary fuels used when fuelwood is scarce, it is assumed that the demand of fuelwood is larger than consumption.

Fuelwood is not only used by households, but also by some industries and miscellaneous institutions. The amount of fuelwood used varies with the type of enterprise, the institution and production process undertaken, the scale of operation, and the efficiency of equipment used (Kgathi and Mlotshwa 1994).

In most cases, basic information on the consumption figures of fuelwood by institutions and industries is as unreliable as that on household use. A few available studies suggest that institutions and industries use large amounts of fuelwood. For example, Hategeka (1997) reported that substantial amounts of fuelwood are used by bakeries $\left(1.71 \mathrm{~m}^{3}\right.$ day $\left.^{-1}\right)$, brickworks $\left(0.96 \mathrm{~m}^{3}\right.$ day $\left.^{-1}\right)$, schools $\left(0.91 \mathrm{~m}^{3}\right.$ day $\left.^{-1}\right)$ and restaurants $\left(0.50 \mathrm{~m}^{3} \mathrm{day}^{-1}\right)$. This historical data has been collected in a specific study site, Capital Kigali, leading to erroneous figures when extrapolated to the national level.

On the extent to which fuelwood is used in government institutions and small scales enterprises, data are scarce and less reliable. Information is generally lacking regarding the amount of fuelwood used to produce a given amount of products. As a result, quantitative comparisons of fuelwood use cannot be accurately made. In general, as more than $90 \%$ of Rwandans depend on fuelwood for cooking meals, most of the demand comes from households, the rest being shared between industries and institutions.

Many authors (e.g. Cline-Cole et al. 1990; Lefevre et al. 1997; Turker and Kaygusuz 2001; Pandey 2002; Bandyipadhyay and Shyamsundar 2002) have identified factors that influence fuelwood consumption. The location of households relative to forest resources, and to urban and rural settings, is one of these factors. Fuelwood consumption studies carried out in Rwanda have not made a clear distinction in per capita fuelwood consumption between rural and urban areas. Only MINECOFIN (2003) made the distribution of households by main source of energy
Table 5 Energy

consumption of resident population in Rwanda in 2002 (MINECOFIN 2003)

\begin{tabular}{|c|c|c|c|c|c|c|}
\hline \multirow[t]{3}{*}{ Energy type } & \multicolumn{6}{|c|}{ Energy use (\%) } \\
\hline & \multicolumn{3}{|c|}{ Cooking } & \multicolumn{3}{|c|}{ Lighting } \\
\hline & Urban & Rural & National & Urban & Rural & National \\
\hline Electricity & 0.7 & 0.0 & 0.1 & 25.9 & 0.6 & 4.6 \\
\hline Private hydro-electric source & & & & 0.1 & 0.0 & 0.1 \\
\hline Solar, plates/electric generator & & & & 0.2 & 0.1 & 0.1 \\
\hline Gas & 0.2 & 0.0 & 0.1 & & & \\
\hline Kerosene/bush lamp & 0.2 & 0.1 & 0.1 & 26.1 & 8.9 & 11.6 \\
\hline Lampion/wicker & & & & 41.7 & 68.7 & 64.4 \\
\hline Candle & & & & 1.8 & 0.2 & 0.5 \\
\hline Firewood/wood & 52.2 & 91.0 & 84.9 & 2.4 & 18.3 & 15.8 \\
\hline Charcoal & 41.3 & 1.2 & 7.5 & & & \\
\hline Vegetal materials & 3.4 & 7.1 & 6.5 & & & \\
\hline Other & 1.3 & 0.1 & 0.3 & 0.7 & 2.4 & 2.2 \\
\hline Not specified & 0.7 & 0.4 & 0.5 & 1.1 & 0.8 & 0.8 \\
\hline Total & 100.0 & 100.0 & 100.0 & 100.0 & 100.0 & 100.0 \\
\hline
\end{tabular}




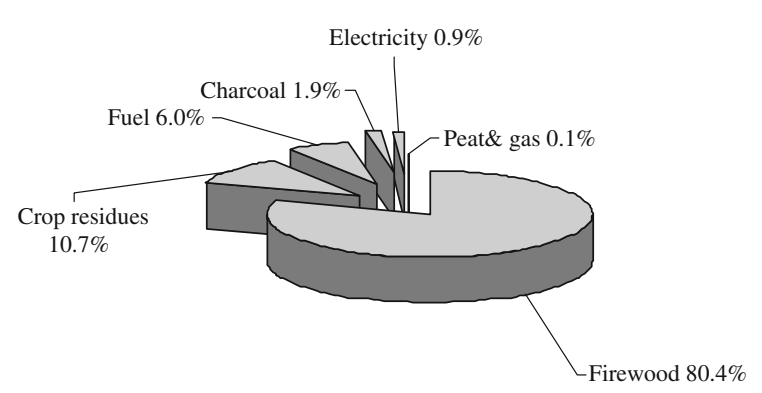

Fig. 3 Contribution of energy sources to total energy consumption in Rwanda in 2005 (MINEFI-DGTPE 2005)

for cooking and lighting by urban and rural residence. Table 5 shows the percentage of the population using different sources of energy for cooking and lighting in both areas in 2002.

From this table, it is clear that wood, as firewood and charcoal, supplies energy for cooking to $92.2 \%$ of the population in rural areas and to $93.5 \%$ of the population in urban areas. The slight difference in the proportion of people using fuelwood between urban and rural areas could be explained by access and more intense use of vegetable materials for energy needs in rural areas. The consumption of vegetable materials is higher in rural areas $(7.1 \%$ of rural dwellers) than in urban areas (3.4\% of urban dwellers). At national level, these materials are used by $6.5 \%$ of the population.

Other sources of energy such as electricity, petroleum products, peat and methane gas are little used compared to fuelwood (Fig. 3). While biomass contributed $93 \%$ of total energy consumption in 2005 , electricity supplied only $0.9 \%$ and fossil fuels accounted for $6.1 \%$ (MINEFI-DGTPE 2005). Petroleum products are used mainly in transport sector, in industry and in lighting at household level. Electricity is rarely used for cooking but finds application in industries, in private and public institutions. In some households, particularly in urban areas, electricity is mainly used for lighting, and for refrigeration.

Though the country has considerable potential of energy sources other than biomass, these have been exploited on much smaller scales. For example the annual hydroelectric power production from four national power stations was $45 \mathrm{MW}$ in 2003 while the potential is estimated at approximately $90 \mathrm{MW}$ (MININFRA 2004). Reserves of methane gas deposits ranging from 55 to 70 billion $\mathrm{m}^{3}$ in Lake Kivu are estimated to potentially produce between $200 \mathrm{MW}$ and $700 \mathrm{MW}$ as recoverable energy potential. Peat reserves amount to 155 millions tonnes of which onethird is an exploitable raw material (MINEFI-DGTPE 2005), albeit not in a sustainable way. The solar energy is little used but has considerable potential as the recorded insulation is nearly $5.2 \mathrm{kWh} \mathrm{m}^{-2}$ day $^{-1}$ (MININFRA 2004). These energetic sources, once fully exploited, present advantages of being easily accessible and available in ample quantities that can be used to substitute fuelwood for use in households, industries and miscellaneous institutions.

In households, cheap and accessible sources of energy are used. The use of fuelwood is predominant in rural areas as well as in urban areas. A study by Leach and Mearns (1988) suggests that even in cities where fuelwood is more expensive than the modern alternatives, people prefer fuelwood because: (i) the supply is more secure, (ii) the fuelwood is available in small, affordable quantities in local markets, and (iii) fuelwood requires no expensive initial investment in cooking stoves. Therefore, to understand urban fuelwood problems, it is essential to understand the structure of urban fuel markets.

Urban dwellers in the capital Kigali have few affordable alternatives to firewood and charcoal for cooking, as all petroleum products and electrical tariffs are comparatively expensive (GTZ 2008). In addition, few urban households, estimated at $26 \%$ of urban dwellers have access to electricity while on national level, electrical connections is estimated to cover only $8 \%$ of the country's area (MININFRA 2004). In addition to other reasons, this leads to increasing cost of fuelwood and charcoal in the capital Kigali. For instance a bag of charcoal of approximately $45 \mathrm{~kg}$ is sold at a retail price of approximately US\$ 12 at the time of this review (2009).

\section{Fuelwood demand and supply balances}

The balance between fuelwood demand and supply in Rwanda has always been estimated based on population data, per capita fuelwood consumption and forest stock, neglecting trees on farms. In 1981, the fuelwood gap calculated as the difference between sustained harvests from forests and the amount of fuelwood consumed was estimated at 2.8 million $\mathrm{m}^{3}$. This gap was 3.0 million $\mathrm{m}^{3}$ in 1990 , and 


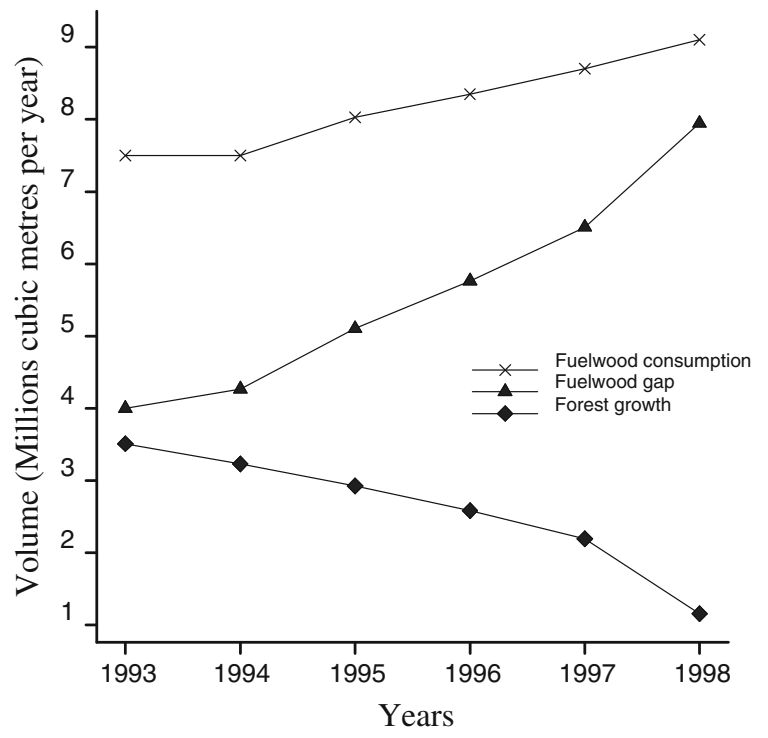

Fig. 4 Fuelwood demand and supply forecast for Rwanda, 1993-1998 (Murererehe 2000)

4.5 million $\mathrm{m}^{3}$ in 1997 (MINITERE 2002). In 2004, the overall wood deficit, including fuelwood, was reported to be 6.7 million $\mathrm{m}^{3}$ (MINITERE 2004c). These data indicate that fuelwood demand has been higher than supplies as estimated from forest stock only, without accounting for the amounts of wood that can be collected from agricultural lands. Using the average of $1.5 \mathrm{~m}^{3} \mathrm{ha}^{-1}$ year $^{-1}$, wood from 1.4 million ha of agricultural lands would be about 2.1 million $\mathrm{m}^{-3}$ year $^{-1}$. As a result, supplies from agricultural lands substantially reduce the projected fuelwood gap. In Fig. 4, the observed pattern indicates that fuelwood demand has been increasing over the years, while total production of forests has been declining.

The consumption of all wood products was projected to follow the same trend as fuelwood consumption. Figure 5 gives a comparison between potential wood removals, wood needs and gaps, from 1960 to 2002. It shows that population growth increases utilization of wood from forests. Already in 1970 , when population size was about 2.7 million, wood forest resources alone were not enough to meet the demand for wood products, including fuelwood. In the following 10-year period, the population increased significantly to reach almost 4.8 million in 1980 . Wood deficit became progressively worse after 1990.

The volume of wood consumed annually carries some level of bias in the estimation because per capita wood consumption was calculated based on the

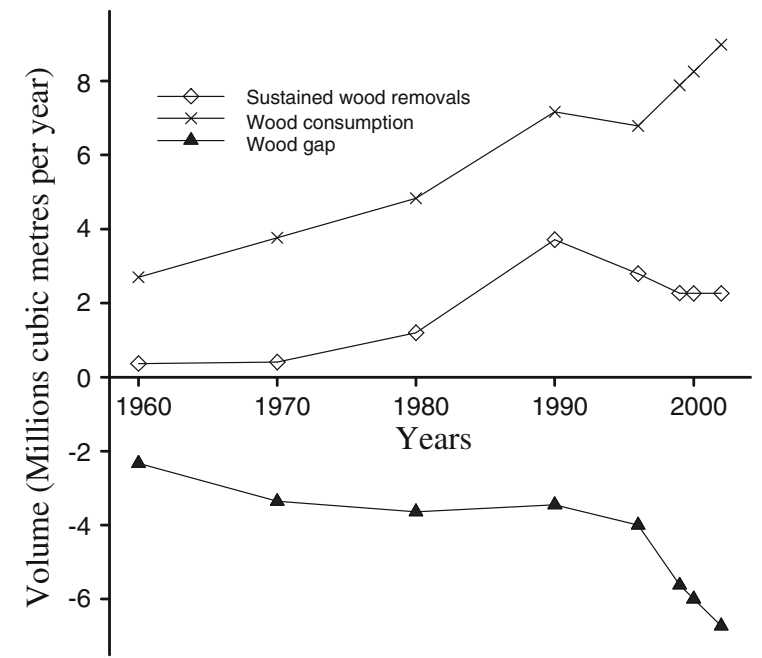

Fig. 5 Needs and sustained yield of wood in Rwanda (MINITERE 2004c)

size of the population assuming that all people consumed equally the same amount of wood and depended only on forests to meet their energy requirements for cooking. Consequently available data on fuelwood demand and supply balances should be interpreted bearing in mind that trees in agricultural fields and other alternative sources of energy for cooking have not been considered in the estimation of fuelwood gaps.

\section{Impact of fuelwood consumption on land use}

In Many Sub-Saharan Africa, rural fuelwood use is often cited as a factor in large-scale deforestation without sufficient evidence (Mercer and Soussan 1992). A study carried out in the Southern African Development Coordination Conference (SADCC) region concluded that rural subsistence households do not cause deforestation (Misana 1988). In Mali, Benjaminsen (1997) found that locally induced deforestation caused by fuelwood use did not represent an immediate problem in rural areas. In Kenya, Mahiri and Howorth (2001) concluded that deforestation and subsequent degradation had little to do with fuelwood consumption as much was extracted from outside the forests. In their review on fuelwood consumption in developing countries, Arnold et al. (2003) concluded that fuelwood supplies come from non-forest resources, hence fuelwood collection by rural dwellers has much less impact as might be concluded from forest supply of fuelwood only. 
Table 6 Protected forests' cover change in Rwanda between 1960 and 1999 (MINITERE 2005)

\begin{tabular}{|c|c|c|c|c|c|c|c|}
\hline \multirow[t]{2}{*}{ Protected forest } & \multicolumn{6}{|c|}{ Forest cover (ha) } & \multirow{2}{*}{$\begin{array}{l}\text { Cover } \\
\text { change }(\%)\end{array}$} \\
\hline & 1960 & 1970 & 1980 & 1990 & 1996 & 1999 & \\
\hline Nyungwe & 114,025 & 108,800 & 97,000 & 97,000 & 94,500 & 89,150 & 21.8 \\
\hline Gishwati & 28,000 & 28,000 & 23,000 & 8,800 & 3,800 & - & - \\
\hline Mukura & 3,000 & 3,000 & 2,000 & 2,000 & 1,600 & 1,600 & 46.7 \\
\hline Birunga & 34,000 & 16,000 & 15,000 & 14,000 & 12,760 & 12,760 & 62.5 \\
\hline Akagera & 267,000 & 267,000 & 267,000 & 241,000 & 220,000 & 90,000 & 66.3 \\
\hline Other $^{\mathrm{a}}$ & 150,000 & 150,000 & 90,000 & 50,000 & 20,000 & - & 86.7 \\
\hline Total & 596,025 & 572,800 & 494,000 & 412,800 & 352,660 & 193,510 & \\
\hline
\end{tabular}

a Gallery forests and savannah woodlands

In Rwanda, between 1960 and 2002, the forest area declined dramatically from 634,000 ha to 221,200 ha, corresponding to a reduction in cover of about $65 \%$ in the last four decades (MINITERE 2005). Table 6 shows the change in forest cover for the main protected forest areas in Rwanda between 1960 and 1999.

The cause of the deforestation in Rwanda between 1960 and 1999 is associated mainly with the need to open up and exploit land area for food production, thereby removing the wood production system. The expansion of agriculture land is generally considered to be the main cause of deforestation in tropical Africa (e.g. Boahene 1998; Adedire 2002; Zhang et al. 2002; Pote et al. 2006). Through this practice, substantial quantities of wood resources are collected for household energy source or either burn on field or left in the agricultural fields. Various reports (e.g. Percival and Homer-Dixon 1995; Gasana 1997; MINITERE 2003) presented additional significant causes of deforestation in order of importance as livestock farming, logging for valuable tree species, collection of wood products including firewood and charcoal production, bush fires, mining, and conflicts and war.

The impact of wood consumption including fuelwood on deforestation has been analysed in relation to total annual wood consumption and annual allowable cut. As a result, some authors (e.g. Gasana 1991; Gasana 1994) estimated that deforestation occurs when the rate of wood harvest is greater than the growth of new stock. From the definition view point, deforestation encompasses the removal of forests leading to change from land use for forest to other land uses, or reduction of forest crown cover to less than 10 percent. Fuelwood gathering in existing forests by rural households is a common practice that normally does not change forest cover. In contrast, commercial exploitation of forests for firewood and charcoal leads to deforestation as it has been the case in the savannah woodlands in the eastern region of Rwanda (Hoster and Milukas 1992).

High deforestation rate was registered after the outbreak of the civil war in 1990 and the genocide that has followed in 1994. During these periods, people were obliged to leave their area and settle elsewhere. Forests were identified as the campsites of these displaced people and hence large forests areas were cleared for shelter, with subsequent collection of fuelwood. The main driving force however, was the need for agricultural land rather than the need for fuelwood.

Immediately after the genocide of 1994, there was spontaneous occupation of the natural ecosystems by Rwandan returnees, aggravating the deforestation. This emergency situation has induced the declassification of the $2 / 3$ of the eastern savannah falling within the Akagera National Park and almost virtual disappearance of Gishwati Forest in the North of the country (MINITERE 2003). In fact, these two ecosystems which are naturally fragile were forced to accommodate considerable numbers of people and cattle, greatly exceeding their carrying capacity. Therefore, the need for land for agriculture and settlement has most forced people to clear forests.

\section{Conclusions}

In Rwanda, forest plantations and agroforestry systems are the main sources of fuelwood. Imprecise estimates of the quantities of fuelwood collected from 
forest plantations are available. However, supplies from agricultural fields have not been quantified while they have a high potential to provide fuelwood on sustainable basis. The current country statistics have not included on-farm tree resources into the energy supplies, making the forecast of fuelwood demand and supply balances doubtful, and leading to overestimation of the gap between wood supply consumption.

Since it is evident that a large part of the demand for fuelwood already comes from agroforestry systems and that agroforestry practices are promoted to ensure agricultural intensification, it should be analysed how much wood can be grown on farmlands, and how much competition this will give to crop yields. The assumption that all fuelwood used by the population comes from forests and thereby resulting in the depletion of forest stock is biased because as the problem of scarcity of fuelwood becomes more severe, the households are forced into a number of coping strategies, which include for instance the consumption of crop residues, the intensive use of tree species on farms and intensive planting of trees.

Given the small size and low productivity of forest plantations, the major source of fuelwood is agroforestry. As a viable option for land management, onfarm trees and woodlots can contribute significantly to fuelwood production in rural areas while improving the overall land productivity. This strategy, however, is only possible on farms with an area equal to or larger than 0.76 ha, because of the basic need for land for crop production. In order to address deforestation, more wood products should be produced on agricultural lands through well managed agroforestry practices and in forest plantations on selected sites. For this, the choice of tree species is crucial, as well as consideration of multipurpose tree species having fuelwood attributes, high biomass production rates and increased positive effects on crop yields.

Acknowledgements This study is part of the PhD Programme at Wageningen University, the Netherlands, funded by Netherlands Organization for international cooperation in higher education (NUFFIC, grant nr. CF2906/2006 under the agreement between Rwanda Agricultural Research Institute (ISAR) and NUFFIC). We are grateful to ISAR for facilitation during this study. We also acknowledge the cooperation and assistance from the Division of Forestry in the Ministry of Natural Resources in Rwanda.
Open Access This article is distributed under the terms of the Creative Commons Attribution Noncommercial License which permits any noncommercial use, distribution, and reproduction in any medium, provided the original author(s) and source are credited.

\section{References}

Adedire MO (2002) Environmental implications of tropical deforestation. Protein Pept Lett 9(2):33-40

AFRENA (1988) Potentiel agroforestier dans les systèmes d'utilisation des sols des hautes terres d'Afrique de l'Est à régime pluviométrique bimodal: Rwanda. ISAR/ICRAF, Butare

Akinnifesi FK, Kwesiga F, Mhango J, Chilanda T, Mkonda A (2006) Towards the development of miombo fruit trees as commercial tree crops in Southern Africa. For Trees Livelihoods 16:103-121

Akinnifesi FK, Harawa R, Sileshi G, Franzel S, Ajayi OC et al (2009) On-farm assessment of legume fallows and other soil fertility management options used by smallholder farmers in southern Malawi. Agric J 4(6):260-271

Amsallem I, Koné PD, Wilkie ML (2002) Status and trends in forest management in central Africa. FAO, Roma

Arnold JEM, Kohlin G, Persson R, Shepherd G (2003) Fuelwood revisited: what has changed in the last decade? Occasional Paper 39. CIFOR, Bogor

Balasubramanian V, Sekayange L (1986). Biological soil fertility management in African Highlands with examples from Rwanda. In: XIII Intl Congr Soil Sci transactions, vol 3, pp 675-676

Balasubramanian V, Sekayange L (1992) Effet de la culture en couloir sur les propriétés du sol et les performances des arbustes et des cultures vivrières dans un environnement semi-aride au Rwanda. Bull Réseau Erosion 12:180-190

Bandyipadhyay S, Shyamsundar P (2002) Fuelwood consumption and participation in community forestry in India. World Bank Policy Working Paper No 331, Washington

Banzi FM, Otsyna R, Assenga D (2004) Soil fertility improvement and maize yields following woodlots of three different species in Shinyanga Tanzania. World Agroforestry Centre (ICRAF), Nairobi

Benjaminsen TA (1997) Is there fuelwood crisis in Mali? GeoJournal 43:163-174

Bird N, Dickson C (2005) Poverty Reduction Strategy Papers: making the case for forestry. ODI forestry briefing No 7. ODI, London

Biroli P (1980) Effort de reboisement au Rwanda. Bulletin Agricole du Rwanda 13:24-29

Biroli P (1982) Le reboisement au Rwanda et ses problèmes. Bulletin Agricole du Rwanda 15(2):122-125

Boahene K (1998) The challenge of deforestation in tropical Africa: reflexions on its principal causes, consequences and solutions. Land Degrad Dev 9:247-258

Böhringer A, Leihner DE (1997) A comparison of alley cropping and block planting systems in sub-humid Benin. Agrofor Syst 35:117-130 
Breman H, Kessler JJ (1995) Woody plants in agro-ecosystems of semi-arid regions. With an emphasis on the Sahelian countries. Advanced Series in Agricultural 23. SpringerVerlag, Berlin

Buresh RJ, Cooper PJM (1999) The science and practice of short-term improved fallows: symposium synthesis and recommendations. Agrofor Syst 47:345-356

Campbell BM, Jeffrey S, Luckert M, Mutamba M, Zindi C (2002) Household livelihoods in semi-arid regions: options and constraints. Center for International Forestry Research, Bogor

Cavendish W (2002) Quantitative methods for estimating the economic value of resource use to rural households. In: Campbell B, Luckert M (eds) Uncovering the hidden harvest: valuation methods for woodland and forest resources. Earthscan, London, pp 17-63

Chirwa TS, Mafongoya PL, Chintu R (2003) Mixed planted fallows using coppicing and non-coppicing tree species for degraded Acrisols in eastern Zambia. Agrofor Syst 59:243-251

CIA (2010) The World Factbook 2010: Rwanda. https://www. cia.gov/library/publications/the-world-factbook/geos/rw. html. Accessed 8 April 2010

Cline-Cole RA, Main HA, Nichol JE (1990) On fuelwood consumption, population dynamics and deforestation in Africa. World Dev 18(4):513-527

Davidson J (1995) Ecological aspects of eucalyptus plantations. In: Proceedings of a regional expert consultation on eucalyptus, 4-8 October, 1993. FAO Regional Office for Asia and the Pacific, Bangkok

Den Biggelaar C (1996) Farmer experimentation and innovation: a case study of knowledge generation processes in agroforestry systems in Rwanda. Community Forestry Case Study Series 12

Den Biggelaar C, Gold MA (1996) Development of utility and location indices for classifying agroforestry species: the case of Rwanda. Agrofor Syst 34(3):229-246

Djimde M (1988) Potentiel agroforestier dans les systèmes d'utilisation des sols des hautes terres d'Afrique de l'Est à régime pluviométrique bimodal: Rwanda. ICRAF, Nairobi

El-Amin EA, Diab IE, Ibrahim S (2001) Influence of Eucalyptus cover on some physical and chemical properties of a soil in Sudan. Commun Soil Sci Plant Anal 32(13-14):2267-2278

FAO (1993) Agroecological land resources assessment for agricultural development planning: a case study of Kenya resources data base and land productivity, Technical Annex 6: fuelwood productivity. The Food and Agricultural Organization of the United Nation, Rome

FAO (2004) Unified bioenergy terminology. The Food and Agricultural Organization of the United Nation, Rome

FAO (2005) State of the world forests. The Food and Agricultural Organization of the United Nation, Rome

Gahigana I (2006) No more eucalyptus trees, says Official. The New Times, Kigali

Gama BM, Otsyina R, Nyadzi GI, Banzi F, Shirima DS, Mumba M (2004) Improved fallows for soil fertility improvement at Tabora in western Tanzania: a synthesis. In: Proceedings of the regional agroforestry conference, World Agroforestry Centre, Nairobi, May 20-24, 2004, pp 131-140
Gasana JK (1991) Le sous-secteur forestier rwandais. Commission Nationale d'Agriculture, Kigali

Gasana JK (1994) L'homme, l'arbre et la forêt au Rwanda: Problèmes d'un pays enclavé et très peuplé. ETH, Zürich

Gasana JK (1997) Factors of ethnic conflict in Rwanda and instruments for a durable peace. In: Bächler G (ed) Federalism against ethnicity: institutional, legal and democratic instruments to prevent violent minority conflicts. Verlag Rüeger Chur, Zurich, pp 107-136

Govere I (2002) Improved tree fallow and natural miombo woodland use in eastern Zambia: the potential of agroforestry in the conservation of indigenous forests. MSc thesis, University of Zimbabwe, Harare

GTZ (2008) Rwanda: biomass energy strategy. Tome 2: the proposed strategy. GTZ, Kigali

Habiyambere T (1999) Etude pour l'élaboration d'un plan d'action stratégique pour la conservation et la gestion de la biodiversité des écosystèmes: Cas du Rwanda. Direction des Forêts, Kigali

Hategeka A (1997) Guidelines for biomass energy policy implementation in Rwanda. In: Kgathi DL, Hall DO, Hategeka A, Sekhwela MBM (eds) Biomass energy policy in Africa: selected case Studies. Energy Policy Research Network, Zed Books, London, pp 145-221

Hoster RH, Milukas MV (1992) Two African woodfuel markets: urban demand, resource depletion, and environmental degradation. Biomass Bioenergy 3:9-24

Jama BA, Mutegi JK, Njui AN (2008) Potential of improved fallows to increase household and regional fuelwood supply: Evidence from western Kenya. Agrofor Syst 73(2):155-166

Kabaluapa NK, Yoo KH, Shannon DA, Kim PS, Wood CW (2008) Alley cropping and terracing effects on surface runoff, soil erosion and loss of plant nutrients. J Environ Hydrol 16(1):1-15

Karenzi PC (1994) Biomass in Rwanda. In: Hall DO, Mao YS (eds) Biomass energy and coal in Africa. Zed Books, London, pp 68-130

Kerkhof P (1990) Agroforestry in Africa: a survey of project experience. Panos Institute, London

Kgathi DL, Mlotshwa CV (1994) Utilization of fuelwood in Botswana: implications for energy policy. AFREPREN, Nairobi

Kwesiga F, Coe R (1994) Potential of short rotation Sesbania fallows in eastern Zambia. For Ecol Manag 64:161-170

Kwesiga FR, Franzel S, Place F, Phiri D, Simwanza CP (1999) Sesbania sesban improved fallows in eastern Zambia: their inception, development and farmer enthousiasm. Agrofor Syst 47:49-66

Leach G, Mearns R (1988) Beyond the woodfuel crisis: people, land, and trees in Africa. Earthscan, London

Lefevre T, Todoc JL, Timilsina GR (1997) The role of wood energy in Asia. The Food and Agricultural Organization of the United Nation, Rome

Mafongoya PL, Dzowela BH (1999) Biomass production of tree fallows and their residual effect on maize in Zimbabwe. Agrofor Syst 47:139-151

Mahiri I, Howorth C (2001) Twenty years of resolving the irresolvable: approaches to the fuelwood problem in Kenya. Land Degrad Dev 12:205-215 
Masozera KM, Alavalapati JRR (2004) Forest dependency and its implications for protected areas management: a case study from the Nyungwe Forest Reserve, Rwanda. Scand J For Res 19(Suppl 4):85-92

Mead DJ (2005) Forests for energy and the role of planted trees. Crit Rev Plant Sci 24:407-421

Mercer DE, Soussan J (1992) Fuelwood problems and solutions. In: Sharma MP (ed) Looking for balance between conservation and development. World Bank, Washington, pp 177-213

Mihigo A (1999) Situation du secteur forestier et des statistiques forestières au Rwanda. Direction des Forêts, MINAGRI, Kigali

MINAGRI (1983) Enquête sur l'utilisation du bois au Rwanda, 1981-1982. Ministère de l'Agriculture, de l'Elevage et des Forêts, Kigali

MINECOFIN (2003) 3rd general census of population, housing of Rwanda-August 2002. Final results, Statistical tables. National Census Service, Kigali

MINEFI-DGTPE (2005) L'énergie et l'eau au Rwanda. Fiche de synthèse. Ambassade de France au Kenya, Nairobi

MININFRA (2004) Sector strategies document of the ministry of infrastructures (2005-2010). Ministry of Infrastructures, Kigali

MINIRENA/CGIS-NUR (2008) Cartographie des Forêts du Rwanda 2007. Rapport Final, vol 1. Ministry of Natural Resources and Environment, Kigali

MINIRENA/ISAR (2008) Inventaire des Ressources Ligneuses du Rwanda. Rapport Final, vol 2. Ministry of Natural Resources and Environment, Kigali

MINITERE (2002) Rapport National du Rwanda sur le Développement Durable et la Mise en œuvre de l'Agenda 21. Ministry of Lands, Environment, Forests, Water and Mines, Kigali

MINITERE (2003) National strategy and action plan for the conservation of biodiversity in Rwanda. Ministry of Lands, Resettlement and Environment, Kigali

MINITERE (2004a) National land policy. Ministry of Lands, Environment, Forests, Water and Mines, Kigali

MINITERE (2004b) Environmental policy. Ministry of Lands, Environment, Forests, Water and Mines, Kigali

MINITERE (2004c) National forestry policy. Ministry of Lands, Environment, Forests, Water and Mines, Kigali

MINITERE (2005) Communication Nationale Initiale Relative à la Convention-cadre des Nations Unies sur les Changements Climatiques. Ministère des Terres, de l'Environnement, des Forêts, de l'Eau et des Mines, Kigali

MINITRAPE (1992) Bulletin de statistiques énergétiques du Rwanda. Ministère des Travaux Publics et de l'Energie, Kigali

Misana SB (1988) The shrinking forests and the problem of deforestation in Tanzania. J East Afr Res Dev 18:108-118

Misra PN, Tewari SK, Singh D, Kayitar RS (1995) Effect of coppicing height on the regeneration and productivity of certain firewood shrubs in alkaline soils of North Indian plains. Biomass Bioenergy 9(6):459-463

Monela GC, Kajembe GC, Kaoneka ARS, Kowero G (1999) Household livelihood strategies in the miombo woodlands of Tanzania. Tanzania J Forest Nat Conservancy 73:17-33
Mukuralinda A, Ndayambaje JD, Marara J et al (1999) Situation de l'Agroforesterie au Rwanda après 1994: Rapport d'enquête. Projet AFRENA-ECA/Rwanda, Butare

Munyarugerero G (1988) Les effets écologiques des eucalyptus en plantation. In: Pleines V (ed) Compte-rendu du premier séminaire national sur la sylviculture des plantations forestières au Rwanda du 31 Août au 3 Septembre 1987. Département de Foresterie de l'Institut des Sciences Agronomiques du Rwanda, Butare, pp 79-89

Murererehe S (2000) Etat des ressources forestières au Rwanda. Rapport technique AFDCA/TR/14. FAO, Kigali

Nair PKR (1987) Agroforestry and firewood production. In: Hall DO, Overend RP (eds) Biomass: renewable energy. Wiley, Chichester, pp 367-386

Nakakaawa CA, Vedeld P, Gombya-Ssembajjwe W (2004) Carbon value and profitability of improved fallow agroforestry systems in Uganda. In: Proceedings of the international conference on economics of sustainable forest management, University of Toronto, Toronto, May 20-22, 2004

Nduwamungu J, Munyanziza E, Ndayambaje JD et al (2007) Eucalyptus in Rwanda: are the blames true or false? Review. In: Njeru RW, Kagabo DM, Ndabamenye T, Kayiranga D, Ragama P, Sallah PYK, Nkerabahizi D, Ndiramiye L, Night G, Akinyemi SOS, Kanuya N (eds) Sustainable agriculture productivity for improved food security and livelihoods. Institut des Sciences Agronomiques du Rwanda, Kigali, pp 289-301

Newmann I, Pietrowicz P (1986) Agroforestrie à Nyabisindu: Etudes et Expériences No 9. Projet Agro Pastoral, Nyabisindu

NISR (2010) National agricultural survey 2008. Results of final data analysis. National Institute of Statistics of Rwanda, Kigali. Available at http://www.statistics.gov.rw/images/ PDF/agricole2008.pdf

Nshubemuki L (1988) Eucalyptus plantations: relationships with and effects on soil and hydrology. In: Pleines V (ed) Compte-rendu du premier séminaire national sur la sylviculture des plantations forestières au Rwanda du 31 Août au 3 Septembre 1987. Département de Foresterie de l'Institut des Sciences Agronomiques du Rwanda, Butare, pp 93-117

Nyadzi GI (2004) Nutrients and water dynamics in rotational woodlots: a case study in Western Tanzania. Wageningen University and Research Centre, Wageningen

Pandey D (2002) Fuelwood studies in India: myth and reality. Centre for International Forestry Research, Jakarta

Percival V, Homer-Dixon T (1995) Environmental scarcity and violent conflict: the case of Rwanda. Occasional Paper, Project on Environment, Population and Security. American Association for the Advancement of Science and the University of Toronto, Washington

Pote J, Shackleton C, Cocks M, Lubke R (2006) Fuelwood harvesting and selection in Valley Thicket, South Africa. J Arid Environ 67:270-287

Pye-Smith C (2008) Farming trees, banishing hunger. how an agroforestry programme is helping smallholders in Malawi to grow more food and improve their livelihoods. World Agroforestry Centre, Nairobi

Roose E, Ndayizigiye F, Sekayange L (1993) L'agroforesterie et la GCES au Rwanda: Comment restaurer la productivité 
des sols acides dans une région tropicale de montagne à forte densité de population? Cah Orstom sér Pédol XXVIII(2):327-349

Samyn JM (1993) Quelques réflexions sur la consommation de combustibles ligneux dans les campagnes Rwandaises. Ministère de l'Agriculture, de l'Elevage et de l'Environnement, Kigali

Sanchez PA, Izac A-M, Valencia IM, Pieri C (1996) Soil fertility replenishment in Africa. In: Breth SA (ed) Achieving greater impact from research investments in Africa. Sasakawa Africa Association, Mexico City, pp 200-208

Sileshi GFK, Akinnifesi FK, Ajayi OC, Place F (2008) Metaanalysis of maize yield response to woody and herbaceous legumes in sub-Saharan Africa. Plant Soil 307:1-19

Turker MF, Kaygusuz K (2001) Investigation of variables effects on fuelwood consumption as an energy source in forest villages of Turkey. Energy Convers Manag 42(10): $1215-1227$

Warner K (2000) Forestry and sustainable livelihoods. Unasylva $51: 3(\mathrm{np})$
Weber AW (1989) Conservation and development on the Zaire-Nil divide: an analysis of value conflicts and convergence in the management of afromontane forests in Rwanda. Dissertation, University of Wisconsin

White KJ (1995) Silviculture of eucalyptus plantings: learning in the region. In: Proceedings of a regional expert consultation on eucalyptus, FAO Regional Office for Asia and the Pacific, Bangkok, 4-8 October, 1993

Yamoah CF, Burleigh JR (1990) Alley cropping Sesbania sesban (L.) Merill with food crops in the highland region of Rwanda. Agrofor Syst 10(2):169-181

Yamoah C, Grosz R, Nizeyimana E (1989) Early growth of alley shrubs in the Highland region of Rwanda. Agrofor Syst 9:171-184

Zhang Q, Justice CO, Desanker PV (2002) Impacts of simulated shifting cultivation on deforestation and the carbon stocks of the forests of central Africa. Agric Ecosyst Environ 9(2):203-209 